\title{
Using of Performance Appraisal Methods in Czech and Slovak Organisations
}

\author{
DOI: 10.12776/QIP.V21I3.890
}

\author{
Hana Urbancová, Katarina Stachová, Zdenko Stacho
}

Received: 22 February 2017 Accepted: 28 October 2017 Published: 30 November 2017

\begin{abstract}
Purpose: People, their knowledge, abilities and skills are considered to be the most valuable source every organisation can exploit. It is, therefore, necessary to care about their fair remuneration and continuing development, as well as their objective and fair appraisal. Implementing an effective appraisal system in the personnel strategy, satisfying both employers and employees, is an essential part of the success of all competing organisations. The aim is to evaluate the use of employee appraisal methods in the selected Czech and Slovak organisations, and to recommend proposals for improvement on the grounds of such evaluation.
\end{abstract}

Methodology/Approach: The data were obtained in two quantitative researches conducted in the selected organisations in the Czech Republic $(n=402)$ and the Slovak Republic $(n=339)$. Univariate analysis, bivariate analysis and analysis of qualitative traits were employed in order to evaluate results.

Findings: The results showed that $58.46 \%$ of the interviewed Czech organisations and $69.32 \%$ of the Slovak organisations had established a formal system of employee appraisal. Most of them were medium-sized enterprises with an HR department, operating in the private sector.

Research Limitation/implication: Limits can be seen in to focus on research in two selected countries, but they have comparable from historical, political and the job market perspectives.

Originality/Value of paper: The article focused on using of modern performance appraisal methods in practice to build the employer's good brand and attract knowledge workers.

Category: Case study

Keywords: human resource management; performance appraisal methods; organisations; the Czech Republic; the Slovak Republic 


\section{INTRODUCTION}

The main objective of performance appraisal is to ensure a maximum exploitation of the abilities, knowledge and interest of each employee (Arthur, 2010). It can therefore be assumed that a suitably set employee appraisal system has a significant impact on both their performance and performance of the whole organisation (Văcărescu Hobeanu, 2015). The employee performance appraisal can be considered to be a basis of making the exploitation of human resources in organisations more effective. Several authors have coincided that the performance appraisal aims at obtaining information and specifying the present level of employees, and especially at setting realistic objectives for further human resource management. A suitably elaborated employee appraisal system not only increases fairness, transparency and effectiveness in employee remuneration but it is also reflected in the correct establishment of employee education procedures, which results in an increased performance at work, as well as improved motivation to the quality of performed work (Lindner and Wald, 2011).

For this and many other reasons, every organisation should deal with the issue of employee appraisal and all related important factors. They, first of all, include the correct selection of methods and appraisal criteria, effective implementation of the appraisal system and purposeful setting of suitable objectives aimed at developing the whole organisation (El Baradei and Newcomer, 2008). The issue of appraisal methods and the whole work appraisal system is also relevant due to the fact that the development of information technology is accompanied by the breakthrough use of electronic environment as an instrument of continuous appraisal process. The employee performance appraisal is among the key problems that should be dealt with continuously by all employers in the presentday turbulent and competitive environment. Based on the knowledge and proper appraisal of employees, organisations can not only efficiently motivate employees but also ensure their fast and sustainable development (Yang and Zhu, 2008). Due to the fact that people have different knowledge, abilities and skills (Levy, 2011), the implementation of a corresponding and effective appraisal system is a necessary part of the success of organisations, and a fair system of the employee appraisal is necessary in order to retain the key employees and valuable information for further human resource management functions. It is obvious that there is no universal and ideal appraisal system in practice, as every organisation has its own specific needs and is affected by different factors (both external and internal). For this reason, this paper is to provide a complete picture of the important issue in human resource management.

The purpose of the paper is to evaluate the use of employee appraisal methods in the selected Czech and Slovak organisations, and to recommend proposals for improvement on the grounds of such evaluation. A partial objective is to examine dependence between the selected qualitative traits and to evaluate the present state of the given issue. 
The first part of the article presents theoretical background together with comparisons of secondary resources. The chapter Results and Discussion includes an analysis and a synthesis of the survey targeted at the application of performance appraisal methods in the Czech and Slovak organisations and their comparison. The results of the survey are subsequently compared to the results of similar surveys conducted abroad, and draft recommendations are presented.

\subsection{Theoretical Background of the Work}

The employee appraisal is closely related to the concept of job performance, as it is an instrument of its management. Performance management is a systematic activity of managers aimed at achieving the corporate strategic objectives by means of achieving the required job performance (Văcărescu Hobeanu, 2015). Job performance is expressed by the quality of work, amount of work, approach to work, etc. The employee appraisal enables managers to achieve the required job performance and corporate strategic objectives by means of checking, guiding and encouraging employees during the performance of their work.

Three groups of employees participate in the implementation and development of an appraisal process. The first group includes the appraised employees (managers and employees to be appraised), the second group includes the appraising employees (both internal and external), and the third group includes so called facilitators (these are mostly the employees of departments of the management and development of human potential), whose role is to facilitate appraisal systems for the whole organisation (Blašková, 2011).

The employee appraisal can be both formal and informal in practice. In the informal appraisal, managers lead employees toward performing the agreed work, while monitoring and assessing their performance continuously. In an event of discrepancies between the actual and required performance, the manager and the employee need to specify a suitable improvement method immediately. The first step in solving a performance problem is to define the problem and identify its causes, which is a basis for decision-making regarding the steps leading to solving the given problem. It is further necessary that managers create conditions for successful problem solving, and that employees subsequently take the agreed steps. At the end, employees receive feedback from their managers in relation to the evaluation of the results of problem solving. Successful problem solving should be the common objective of both employees and managers. In contrast to the informal appraisal, formal appraisal, on which this paper is primarily focused, is performed by an appraisal interview, when managers inform employees, and discuss not only their performance but also their abilities, motivation and conditions with them (Hitka, et al., 2017). The aforementioned indicates that a suitably performed formal appraisal should provide a possibility to clarify the attitudes of both the appraised and appraising employees, taking into account that each of them can have a different apprehension and thus different measures of importance in appraising individual activities (Snell and 
Bohlander, 2010). In this way, misunderstandings and uncertainties in the decisions of subordinates can be prevented and their proper understanding and performance by superiors can be ensured (Yang and Zhu, 2008). The outcome of the formal appraisal is a report (appraisal form), which is a part of personnel records, and which supports managers in their decisions concerning performance management.

Generally, the employee appraisal in organisations is regular and continuous, frequently supplemented by the special appraisal, which is irregular. With regard to the frequency of appraisals, appraisal types are divided into short-term, longterm and special. In the short-term appraisal, only performance is appraised, and the results are used for further long-term appraisal. It is a regular appraisal after several weeks of work with a focus on feedback and relationship between the appraised and appraising employees, typically conducted during or after the end of a trial period. The long-term appraisal should be conducted at least once in six months, i.e. it is also regular. Not only performance but also the competence of employees and their general approach to work are assessed. It is characterised by observing individual competences and tasks with regard to records on performances over a reporting period. Future development is forecast, and careers are planned and arranged by the employees and managers managing their further careers. For this reason, comprehensive information on appraisal criteria needs to be available for employees. On the basis of such comprehensive information on all attributes, responsibilities, values, standards, required behaviour and expected results, which will be a subject of appraisal, the employees can adapt their efforts to the appraisal criteria and achieve even above average results. The irregular special appraisal is applied in the situations when requirements for the competences of the appraised are not in line with the reality and expectations of employers.

The following three basic reasons why it is suitable to conduct the employee appraisal can be identified. They include increased performance, harmonisation of the interests of all participated parties and improvement of organisational structure. From the viewpoint of organisations, they predominantly include an impact on the increased performance of individuals, streamlined communication at individual levels of management and development of employee potential (El Baradei and Newcomer, 2008). By means of appraisals, managers are able to provide a fair performance assessment, to motivate and develop employees as well as to minimise their weaknesses. In employees' terms, they have an opportunity to express their needs, goals and development demands, to receive feedback on their work and thus a motivation to further efforts (Kromrei, 2015).

It can be assumed that the employee appraisal methods help observe standard performance and behaviour, thus supporting the overall appraisal (Evans and Davis, 2015). There are a number of methods created in order to ensure an optimum employee appraisal (Kromrei, 2015), frequently distinguished depending on time. The first group concerns the appraisal focused on the past, i.e. on the already given performance. The second group concerns the future, i.e. 
employee potential. According to Snell and Bohlander (2010), the most frequently used employee appraisal methods based on the examined groups include the methods focused on the past (management by specified objectives, comparison to standard performance, testing and observing of performance, appraisal questionnaire, rating scale, BARS method, the method of critical events, appraisal reports and employee comparison), and the methods focused on the future (self-appraisal (Chianchana and Wichian, 2016; Kromrei, 2015), Development Centre (El Baradei and Newcomer, 2008), 360 Degree Feedback (Hageman, et al., 2015), 540 Degree Feedback and mystery shopping, or mystery consumer (Wilson, 2001)).

With regard to the aforementioned, every appraisal system should satisfy the conditions of the same appraisal of individuals regardless of an appraiser, minimise the bias and mistakes of appraisers, and, first of all, it should measure the performance aspects which are substantial for the organisation. Further preconditions of effective appraisal include suitably established appraisal criteria and their principles (Văcărescu Hobeanu, 2015). However, proper implementation of an appraisal system needs to be underlined, taking into account that such a system might be implemented for up to 2 - 3 years. A longer time horizon is thus concerned, during which the implementation should proceed from top management toward executives (Diaz-Fernandez, Bornay-Barrachina and Lopez-Cabrales, 2015). A quality setting of the appraisal system can enable organisations to ensure the motivation and orientation of employees toward specified objectives, strengthened loyalty of the employees, feedback on performance as well as a basis for the remuneration and development of employees.

\section{METHODOLOGY}

Primary data were obtained from a quantitative research conducted in organisations operating in the Czech Republic in all sectors of the economy (based on the CZ-NACE). The research was conducted electronically from September 2015 to June 2016. The questionnaire was completed by mid-level and top managers of these organisations. The questions employed specialist terms generally known to mid-level and top management. For potentially ambiguous questions, terms were explicitly defined. The results are focused on the managerial aspects and marginally on the economic aspects. The survey comprised 12 questions and 4 identification questions on the performance appraisal methods. The formulation of questions resulted from co-operation with School of Economics and Management in Public Administration in Bratislava.

The total number of $n=402$ organisations (774 organisations were addressed, the response rate was $51.90 \%$ ) participated in the questionnaire research, which was conducted throughout all economic sectors in the Czech Republic in the monitored period from $1^{\text {st }}$ September 2015 to $30^{\text {th }}$ June 2016. The total number of $\mathrm{n}=339$ organisations (540 organisations were addressed, the response rate was 
$62.78 \%)$ participated in the research in the Slovak Republic. The organisations were selected exclusively for the purpose of the given survey and their composition is random, not respecting the precise shares in national economy. The questionnaire respected the ethical viewpoint and anonymity of respondents.

The structure of Czech organisations participating in the survey was as follows: the business sector: $70.65 \%$ private sector, $14.43 \%$ public sector, $14.93 \%$ state sector; the business field: primary $3.00 \%$, secondary $27.10 \%$, tertiary $69.90 \%$; the market of operation of the given organisations: $12.19 \%$ local, $23.63 \%$ regional, $26.37 \%$ national, $37.81 \%$ international; the organisation is part of a multinational company: $50.00 \%$ yes, $50.00 \%$ no; the size of organisation: $50-249$ of employees $65.92 \%, 250$ or more employees $34.08 \%$. The research concerned organisations with the assumed existence of an HR department, which is why the category of $50^{+}$employees is significant for the research.

The structure of Slovak organisations participating in the research was as follows: the business sector: $70.06 \%$ private sector, $17.65 \%$ public sector, $5.29 \%$ state sector; the business field: primary $5.88 \%$, secondary $33.53 \%$, tertiary $60.59 \%$; the market of operation of the given organisations: $8.37 \%$ local, $12.71 \%$ regional, $30.54 \%$ national, $47.88 \%$ international; the organisation is part of a multinational company: $59.00 \%$ yes, $41.00 \%$ no; the size of organisation: $50-249$ of employees $67.85 \%, 250$ or more employees $32.15 \%$. The research concerned organisations with the assumed existence of an HR department, which is why the category of $50^{+}$employees is significant for the research.

Closed or semi-open questions, which were compiled on the basis of the study of literature, documents and other related research, were used to obtain answers. In order to evaluate the results, descriptive statistical tools such as absolute and relative frequencies, dependence tests $\left(\chi^{2}\right.$ test $)$ and tests of strength dependence (Cramer's V) were used (Anderson, 2009). If the p-value was lower than $\alpha=$ 0.05 , the null hypothesis was rejected. The scale according to De Vaus (2002) was used. Five basic null hypotheses were tested in both Slovakia and Czech Republic, discovering dependence between the selected qualitative traits. The following null hypotheses were tested:

- There is no statistical dependence between setting a formal employee appraisal system and the sector of operation of the interviewed Czech/Slovak organisations.

- There is no statistical dependence between setting a formal employee appraisal system and the size of the interviewed Czech/Slovak organisations.

- There is no statistical dependence between setting a formal employee appraisal system and the existence an HR department in the interviewed Czech/Slovak organisations. 
- There is no statistical dependence between setting a formal employee appraisal system and the type of market on which the interviewed Czech/Slovak organisations operate.

- There is no statistical dependence between whether the interviewed Czech/Slovak organisations are a part of a larger group of institutions and setting a formal employee appraisal system.

To evaluate the data, the SPSS 23 statistical software and MS Excel 2010 were used.

\section{RESULTS}

The representatives of the interviewed Czech organisations declared that $58.46 \%$ (235) of organisations had established a formal employee appraisal system, and $41.54 \%$ (167) of them had not established it yet. The Slovak organisations declared that $69.32 \%$ (235) of organisations had established a formal employee appraisal system, and 30.68\% (104) of them had not established it. In the Czech Republic, a formal appraisal system had been most frequently established by large organisations $(48.51 \%)$ with more than 250 employees and with an HR department.

In the Slovak Republic, a formal appraisal system had been established by $80.73 \%$ of large organisations and $63.91 \%$ of medium organisations. Contingency tab. 1-5 show dependence between the existence of a formal employee appraisal system and individual selected qualitative traits (see Material and Methods).

Table 1 - Contingency Table of Dependence (Existence of a Formal Appraisal System $\times$ Sector)

\begin{tabular}{|l|c|c|c|c|c|c|c|c|}
\hline \multirow{2}{*}{$\begin{array}{c}\text { Formal } \\
\text { appraisal } \\
\text { system }\end{array}$} & \multicolumn{2}{|c|}{ Czech Republic - sector } & \multirow{2}{*}{ Total } & \multicolumn{2}{|c|}{ Slovak Republic - sector } & \multirow{2}{*}{ Total } \\
\cline { 2 - 4 } \cline { 6 - 7 } & Private & State & Public & & Private & State & Public & \\
\hline Yes & 157 & 43 & 35 & $\mathbf{2 3 5}$ & 182 & 13 & 40 & $\mathbf{2 3 5}$ \\
\hline No & 127 & 17 & 23 & $\mathbf{1 6 7}$ & 79 & 7 & 18 & $\mathbf{1 0 4}$ \\
\hline Total & 284 & 60 & 58 & $\mathbf{4 0 2}$ & 261 & 20 & 58 & $\mathbf{3 3 9}$ \\
\hline
\end{tabular}

Tab. 1 showed that in the Czech and Slovak Republics, a formal appraisal system had been established by mostly private sector organisations $(66.81 \%$ in the Czech Republic; $77.45 \%$ in the Slovak Republic).

Tab. 2 showed that in the Czech Republic, a formal appraisal system had been established by mostly medium-sized organisations $(51.48 \%)$ as well as in the Slovak Republic (medium-sized organisations in $62.55 \%$ ). 
Table 2 - Contingency Table of Dependence (Existence of a Formal Appraisal System x Size of Organisation)

\begin{tabular}{|l|c|c|c|c|c|c|}
\hline \multirow{2}{*}{$\begin{array}{c}\text { Formal } \\
\text { appraisal } \\
\text { system }\end{array}$} & \multicolumn{2}{|c|}{ Czech Republic - size } & \multirow{2}{*}{ Total } & \multicolumn{2}{|c|}{ Slovak Republic - size } & \multirow{2}{*}{ Total } \\
\cline { 2 - 3 } \cline { 5 - 6 } & $\mathbf{5 0 - 2 4 9}$ & $\mathbf{2 5 0}^{+}$ & & $\mathbf{5 0 - 2 4 9}$ & $\mathbf{2 5 0}^{+}$ & \\
\hline Yes & 121 & 114 & $\mathbf{2 3 5}$ & 147 & 88 & $\mathbf{2 3 5}$ \\
\hline No & 144 & 23 & $\mathbf{1 6 7}$ & 83 & 21 & $\mathbf{1 0 4}$ \\
\hline Total & 265 & 137 & $\mathbf{4 0 2}$ & 230 & 109 & $\mathbf{3 3 9}$ \\
\hline
\end{tabular}

Table 3 - Contingency Table of Dependence (Existence of a Formal Appraisal System $x$ the Existence of an HR Department)

\begin{tabular}{|c|c|c|c|c|c|c|}
\hline \multirow[t]{2}{*}{$\begin{array}{c}\text { Formal } \\
\text { appraisal } \\
\text { system }\end{array}$} & \multicolumn{2}{|c|}{$\begin{array}{l}\text { Czech Republic - the } \\
\text { existence of an HR } \\
\text { department }\end{array}$} & \multirow[t]{2}{*}{ Total } & \multicolumn{2}{|c|}{$\begin{array}{c}\text { Slovak Republic - the } \\
\text { existence of an HR } \\
\text { department }\end{array}$} & \multirow[t]{2}{*}{ Total } \\
\hline & Yes & No & & Yes & No & \\
\hline Yes & 158 & 77 & 235 & 201 & 34 & 235 \\
\hline No & 36 & 131 & 167 & 25 & 79 & 104 \\
\hline Total & 194 & 208 & 402 & 226 & 113 & 339 \\
\hline
\end{tabular}

Tab. 3 showed that in the Czech and Slovak Republics, a formal appraisal system had been established by mostly the organisations having an HR department, which helps the managing employees to set appraisal processes $(67.23 \%$ in the Czech Republic; $85.53 \%$ in the Slovak Republic).

Table 4 - Contingency Table of Dependence (Existence of a Formal Appraisal System $x$ Market)

\begin{tabular}{|c|c|c|c|c|c|c|c|c|c|c|}
\hline \multirow{2}{*}{$\begin{array}{c}\text { Formal } \\
\text { appraisal } \\
\text { system }\end{array}$} & \multicolumn{4}{|c|}{ Czech Republic - market } & \multirow[t]{2}{*}{ Total } & \multicolumn{4}{|c|}{ Slovak Republic - market } & \multirow[t]{2}{*}{ Total } \\
\hline & 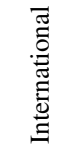 & 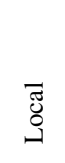 & 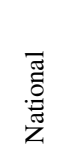 & 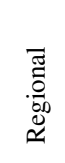 & & 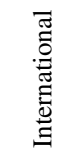 & $\begin{array}{l}\bar{\Xi} \\
\text { త్త }\end{array}$ & 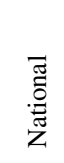 & 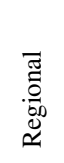 & \\
\hline Yes & 106 & 23 & 64 & 42 & 235 & 94 & 23 & 77 & 41 & 235 \\
\hline No & 46 & 26 & 42 & 53 & 167 & 12 & 27 & 30 & 35 & 104 \\
\hline Total & 152 & 49 & 106 & 95 & 402 & 106 & 60 & 107 & 76 & 339 \\
\hline
\end{tabular}

Tab. 4 showed that in the Czech and Slovak Republics, a formal appraisal system had been established by mostly the organisations operating on the global market (45.11\% in the Czech Republic; $40 \%$ in the Slovak Republic). 
Table 5 - Contingency Table of Dependence (Existence of a Formal Appraisal System $x$ Part of a Group of Organisations)

\begin{tabular}{|c|c|c|c|c|c|c|}
\hline \multirow{2}{*}{$\begin{array}{c}\text { Formal } \\
\text { appraisal } \\
\text { system }\end{array}$} & $\begin{array}{c}\text { Czech Republic - part of a } \\
\text { larger group of } \\
\text { organisations }\end{array}$ & \multirow{2}{*}{ Total } & \multicolumn{2}{|c|}{$\begin{array}{c}\text { Slovak Republic - part of a } \\
\text { larger group of } \\
\text { organisations }\end{array}$} & Total \\
\cline { 2 - 3 } & Yes & No & & Yes & No & \\
\cline { 2 - 6 } Yes & 149 & 86 & $\mathbf{2 3 5}$ & 136 & 99 & $\mathbf{2 3 5}$ \\
\hline No & 52 & 115 & $\mathbf{1 6 7}$ & 41 & 63 & $\mathbf{1 0 4}$ \\
\hline Total & 201 & 201 & $\mathbf{4 0 2}$ & 177 & 152 & $\mathbf{3 3 9}$ \\
\hline
\end{tabular}

Tab. 5 showed that in the Czech and Slovak Republics, a formal appraisal system had been established by mostly the organisations being part of a larger group of organisations (63.40\% in the Czech Republic; 57.87\% in the Slovak Republic).

With regard to the obtained data, the following was discovered as a result of testing the statistical dependence:

- There is no statistical dependence between the sector of operation of the studied Czech/Slovak organisations and setting a formal employee appraisal system $(\mathrm{p}$-value $=0.062 ; \mathrm{p}$-value $=0.971)$.

- Statistical dependence was discovered between the size of the interviewed Czech organisations and setting a formal employee appraisal system ( $\mathrm{p}$-value $=0.000$, Cramer's V $=0.423$, significant dependence), however no dependence between the studied traits was recorded in Slovakia (p-value $=0.319)$.

- Statistical dependence was discovered between the existence of an HR department in the interviewed Czech organisations and setting a formal employee appraisal system ( $\mathrm{p}$-value $=0.000$, Cramer's $\mathrm{V}=0.450$, significant dependence), however no statistical dependence between the studied traits was recorded in Slovakia ( $\mathrm{p}$-value $=0.229$ ).

- Statistical dependence was discovered between the market on which the interviewed Czech organisations operated and setting a formal employee appraisal system ( $\mathrm{p}$-value $=0.000$, Cramer's $\mathrm{V}=0.216$, low dependence), but no statistical dependence between the studied traits was recorded in Slovakia ( $\mathrm{p}$-value $=0.028)$; however, the theoretical frequency was not fulfilled, as $46.7 \%$ of the values were lower than 5).

- Statistical dependence was discovered between whether the interviewed Czech organisations were part of a larger group of institutions and setting a formal employee appraisal system ( $\mathrm{p}$-value $=0.000$, Cramer's $\mathrm{V}=$ 0.318 , moderate dependence), but no dependence was recorded in Slovakia ( $\mathrm{p}$-value $=0.024)$; however, the theoretical frequency was not fulfilled, as $33.3 \%$ of the values were lower than 5). 
Out of the hypotheses tested in the Czech Republic, 4 H0 were rejected, accepting alternative hypotheses, and $1 \mathrm{H} 0$ was accepted, while all null hypotheses were accepted in the interviewed Slovak organisations. In the studied Czech organisations, this formal employee appraisal system was most frequently used for specialists $(28.98 \%)$, followed by management (27.62\%), administrative employees (26.71\%), and manual workers (16.69\%). In the studied Slovak organisations, the formal employee appraisal system was least frequently used for management $(54.12 \%)$, with increasing figures for specialists $(55.29 \%)$, administrative employees (57.65\%) and manual workers (up to 62.65\%). The survey was further focused on whose opinion was requested upon obtaining information in relation to employee appraisal. Detailed results compared to the Slovak Republic are provided in Tab. 6 (more than one answer could be indicated).

Table 6 - Sources of Obtaining Information in the Framework of Employee Appraisal

\begin{tabular}{|l|c|c|c|c|}
\hline \multirow{2}{*}{ Opinion } & \multicolumn{2}{|c|}{ Czech Republic } & \multicolumn{2}{c|}{ Slovak Republic } \\
\cline { 2 - 5 } & $\begin{array}{c}\text { Absolute } \\
\text { frequency }\end{array}$ & $\begin{array}{c}\text { Relative } \\
\text { frequency }\end{array}$ & $\begin{array}{c}\text { Absolute } \\
\text { frequency }\end{array}$ & $\begin{array}{c}\text { Relative } \\
\text { frequency }\end{array}$ \\
\hline Direct superiors & 229 & 46.54 & 167 & 51.38 \\
\hline Senior employees & 71 & 14.43 & 66 & 20.31 \\
\hline Employees themselves & 123 & 25.00 & 42 & 12.92 \\
\hline Subordinates & 15 & 3.05 & 15 & 4.62 \\
\hline Colleagues & 22 & 4.48 & 21 & 6.46 \\
\hline Customers & 29 & 5.89 & 12 & 3.69 \\
\hline Other (not applied) & 3 & 0.61 & 2 & 0.62 \\
\hline
\end{tabular}

The methods of employee appraisal used by the organisations were further studied in the survey. The participating organisations which declared at the beginning of the survey that they had established a formal appraisal system $(n=235)$ could indicate more than one answer. The detailed answers of the interviewed Czech and Slovak organisations are provided in Tab. 7. 
Table 7 - Using of Performance Appraisal Methods in the Czech and Slovak Organisations

\begin{tabular}{|l|c|c|c|c|c|c|c|c|}
\hline \multirow{2}{*}{ Methods } & \multicolumn{3}{|c|}{ Employee category in CZ } & \multicolumn{3}{|c|}{ Employee category in SR } \\
\cline { 2 - 10 } & $\mathrm{M} \%$ & $\mathrm{~S} \%$ & $\mathrm{~A} \%$ & $\mathrm{~W} \%$ & $\mathrm{M} \%$ & $\mathrm{~S} \%$ & $\mathrm{~A} \%$ & $\mathrm{~W} \%$ \\
\hline $\begin{array}{l}\text { Appraisal based on complying with } \\
\text { standards }\end{array}$ & 13.45 & 13.60 & 15.87 & 26.76 & 12.73 & 15.47 & 15.83 & 31.73 \\
\hline Appraisal based on key events & 14.27 & 13.17 & 10.10 & 9.30 & 8.42 & 5.08 & 6.11 & 4.17 \\
\hline Evaluation questionnaire & 7.88 & 10.13 & 10.74 & 8.17 & 11.91 & 13.16 & 17.50 & 12.18 \\
\hline Observation & 6.79 & 8.83 & 9.62 & 18.59 & 2.67 & 4.62 & 4.72 & 8.71 \\
\hline Appraisal interview & 17.26 & 18.38 & 19.39 & 13.80 & 17.25 & 21.02 & 26.39 & 19.55 \\
\hline Self-appraisal & 14.13 & 14.04 & 13.30 & 5.92 & 9.45 & 9.47 & 11.67 & 5.13 \\
\hline Management audit & 2.71 & 1.45 & 0.95 & 0.56 & 9.24 & 3.70 & 1.94 & 0.96 \\
\hline $\begin{array}{l}\text { Appraisal based on fulfilment of } \\
\text { objectives }\end{array}$ & 22.69 & 20.26 & 20.03 & 16.90 & 25.67 & 24.94 & 15.28 & 17.63 \\
\hline Development centre & 0.82 & 0.14 & 0.00 & 0.00 & 2.67 & 2.54 & 0.27 & 0.00 \\
\hline
\end{tabular}

The total of $93.62 \%$ of the participating Czech organisations having a formal appraisal system indicated that their employees were provided the results of the appraisal (regardless of the method of its execution), and were given an opportunity to comment on them, while $3.40 \%$ of the participating organisations indicated that their employees were made familiar with the appraisal results however without a possibility to comment on them. Employees were not made familiar with the appraisal results and had no possibility to comment on them in only $2.98 \%$ of the organisations. In the studied Slovak organisations, employees had a possibility to comment on their appraisal results in up to $75.2 \%$ of the organisations, they were made familiar with the appraisal results however without room for commenting on them in $11.6 \%$ of the organisations, and employees were not even made familiar with their appraisal results in $13.2 \%$ of the organisations. The results obtained from employee appraisals were subsequently used by the interviewed Czech organisations in the areas of remuneration $(33.76 \% \mathrm{CZ} ; 43.85 \% \mathrm{SR})$, education and development of employees (24.76\% CZ; $23.20 \%$ SR), personnel development or career growth (23.95\% CZ; 19.37\% SR), and personnel planning (17.53\% CZ; $13.57 \% \mathrm{SR})$.

\section{DISCUSSION}

Based on the researches of El Baradei and Newcomer (2008), and Kromrei (2015), employee appraisal can be referred to as a comprehensive and difficult process. However, effective human resource management would not dispense with a functional employee appraisal system. The employee appraisal helps 
organisations choose an employee suitable for the given position, identify and efficiently utilise the key competence of employees, motivate them and increase their motivation, provide feedback, tailor positions to the abilities of employees, and educate them properly. At the same time, appraisal systems are interconnected with other human resource management systems, such as remuneration and education. Appraisal systems would not be complete without these two components. A system is comprising strategic corporate objectives suitably interconnected with human resource management objectives, or suitably selected appraisal methods using suitably selected appraisal criteria in accordance with appraisal objectives, can be considered to be an effective appraisal system (Evans and Davis, 2015). It is important for every organisation to succeed in the modern globalised and competitive environment, which can be achieved through the quality performance of employees, which can be affected by the appraisal system (Diaz-Fernandez, Bornay-Barrachina and LopezCabrales, 2015). The motivation-based approach is likely to be the most important of all the approaches to appraisal, as the whole appraisal is especially conducted because of the possibility to motivate performers more efficiently (Blašková, 2011). The appraisal itself also has a positive impact on the motivation of appraisers, as their motivation increases with realising the interconnection between the quality of their appraisal and the level of utilisation of the potential of appraised employees (Bernardin and Beatty, 1984).

With regard to the fact that employee appraisal reveals the actual level of the labour potential of a company along with the possibilities of its better exploitation, the analysis of the present state of performance appraisal clearly demonstrates that both Czech and Slovak organisations necessarily need to change their approaches in order to increase and better exploit the potential of their employees. The conviction of managers of the necessity to implement an effective formal employee appraisal process is a priority, with subsequent necessary correct choice of the appraisal criteria and methods, which can become an instrument of a line manager to regulate the behaviour and action of employees. On the basis of the results of the questionnaire research, bottlenecks which occurred in the organisations can be identified on the grounds of answers indicated by the interviewed $\mathrm{Czech} /$ Slovak organisations. The frequency of an appraisal process is concerned, when the appraisal frequency is more than two years, however employee appraisal on an annual, half year and even quarterly basis is more suitable in some industries. It is essential to realise that the frequency of appraisal should enable an appraisal process to provide a relevant answer to the performance and potential of each employee. The advantages of more frequent appraisal include the early recognition and subsequent solution of both work and personal problems, improved communication between employees and managers, and more frequent exchange of feedback. In terms of the rationality of the work of both a manager and employees, it is necessary to consider also the fact that each formalised appraisal process disrupts the continuity of business processes in a certain extent (Wong, 2009), which is why the length of an appraisal interview not exceeding an hour needs to be ensured. 
Expenses related to the effective setting of a personnel process include time and financial units expendable for an interview as well as administrative costs related to the more frequent appraisal. The implementation of changes is a competence of HR departments, which present proposed changes to management, and individual managers inform their subordinates on the approved proposals.

It is further necessary in the effective appraisal process implementation in organisations to care about comprehensibility and to reduce the time involved, which can be practically ensured by e.g. introducing electronic appraisal forms; however information is confidential, and information security thus needs to be ensured in the information systems. By regular communication of the principle of appraisal interviews, appraisal criteria and news in this area from executives to subordinates, bottlenecks in the communication process can also be eliminated. Bottlenecks related to a lack of information can be eliminated by means of training in communication and management of employees, while it is suitable to hold such training always before initiating regular job interviews. Such training should be organised by HR departments and should be offered to all senior positions. The current trends in the area of appraisal include gamification, personal dashboard interconnected with analysis, graphs assessing advancement and performance (interconnection with the KPI - Key Performance Indicators) or other assessment metrics.

According to Snell and Bohlander (2010), it can be stated that employees are most frequently motivated by their organisations to higher performance by financial remuneration. It is therefore suitable to interconnect appraisal results with remuneration, i.e. to increase the awareness of the interconnection of an appraisal system with the system of education and remuneration in the organisation, which is also confirmed by Shih and Huang (2011). The research of Pardey and May (2014) demonstrated that the efficiency of financial bonuses could be increased by a clear explanation of the conditions of appraisal and of receiving such bonuses to employees. Last but not least, it is necessary to realise that the current trend in appraisal is to appraise whole teams, as the appraisal of both effectiveness and impact of individual teams makes the most sense to organisations, which is also confirmed by the researches of Chianchana and Wichian (2016). The appraisal of individual performances is less important than building a highly effective team nowadays.

\section{CONCLUSION}

Employee appraisal is an indispensable part of human resource management in every organisation, and its results are important not only for the management of the organisation but also for each of its employees. The applied appraisal methods have changed, and formal appraisal systems are not only based on completing an appraisal form any more. In the appraisal process, employees receive feedback on their performance and employers can plan the personal development of such employees as well as the team development on the grounds 
of appraisal results. Every organisation needs to put emphasis on the method of executing and assessing appraisal as well as on how it will communicate its importance to both managers and employees. The results showed that the most frequently used method of employee appraisal is the appraisal interview and the least used method is the Development Centre. The total of $93.62 \%$ of the participating Czech organisations having a formal appraisal system indicated that their employees were provided the results of the appraisal (regardless of the method of its execution), and were given an opportunity to comment on them, while employees had an opportunity to comment on their appraisal results in $75.2 \%$ of Slovak organisations. No statistical dependence was recorded between the sector of the economy and setting a formal appraisal system in the interviewed Czech and Slovak organisations. It can therefore be assumed that the employee appraisal is an essential element in the private, public and state sectors of the economy. The practical contribution of the article is a presentation of the results of the survey conducted in the Czech and Slovak organisations, and identification of the appraisal methods most frequently used in relation to individual employee categories, including recommendations to improve the appraisal process. The theoretical contribution of the article is a comparison of the opinions of foreign authors on the given issue. With regard to the fact that the employee appraisal is a topical issue within human resource management, it would be suitable to focus further research on discovering a dependence between individual appraisal results and remuneration systems implemented in the organisations.

\section{ACKNOWLEDGMENTS}

This contribution is a follow-up to the project of University of Economics and Management in Prague, grant number GCES0415 and School of Economy and Management of Public Administration in Bratislava - Internal Grant Agency 2/2016 Contribution of Selected Attributes of Managerial Work to Creation of Internal Environment Supporting Competitiveness of Companies.

\section{REFERENCES}

Arthur, D., 2010. 70 tipů pro hodnocení pracovníků. Prague: GRADA.

Anderson, V., 2009. Research Method in Human Resource Management. London: Chartered Institute of Personnel Development.

Bernardin, H.J. and Beatty, R.W., 1984. Performance appraisal: Assessing human behavior at work. Boston: Kent.

Blašková, M., 2011. Rozvoj l’udského potenciálu Motivovanie, komunikovanie, harmonizovanie a rozhodovanie. Žilina: Edis. 
Diaz-Fernandez, M., Bornay-Barrachina, M. and Lopez-Cabrales, A., 2015. Innovation and firm performance: the role of human resource management practices. Evidence-based HRM, 3 (1), pp.64-80.

De Vaus, D., 2002. Surveys in Social Research. London: Routledge/Taylor and Francis.

El Baradei, L. and Newcomer, K.E., 2008. A human capital management assessment tool for identifying training and development needs: application to Egyptian public organisations. International Journal of Public Sector Performance Management, 1(2), pp.119-149.

Evans, W.R. and Davis, W.D., 2015. High-Performance Work Systems as an Initiator of Employee Proactivity and Flexible Work Processes. Organisation Management Journal, 12(2), pp.64-74.

Hageman, M.G.J.S., Ring, D.C., Gregory, P.J., Rubash, H.E. and Harmon, L., 2015. Do 360-degree Feedback Survey Results Relate to Patient Satisfaction Measures?. Clinical Orthopaedics and Related Research, 473(5), pp.1590-1597.

Hitka, M., Lorincová, S., Ližbetinová, L. and Schmidtová, J., 2017. Motivation Preferences of Hungarian and Slovak Employees are Significantly Different. Periodica Polytechnica Social and Management Sciences, 25(2), pp.117-126.

Chianchana, C. and Wichian, S.N., 2016. Assessment of performance competency in the organization: Dimensionality oriented assessment. Polish Journal of Management Studies, 13(2), pp.27-35.

Kromrei, H., 2015. Enhancing the annual performance appraisal process: Reducing biases and engaging employees through self-assessment. Performance Improvement Quarterly, 28(2), pp.53-64.

Lindner, F. and Wald, A., 2011. Success factors of knowledge management in temporary organizations. International Journal of Project Management, 29, pp.877-888.

Levy, M., 2011. Knowledge retention: minimizing organizational business loss. Journal of Knowledge Management, 15(4), pp. 582-600.

Pardey, D. and May, T., 2014. Paper 4: Motivation and Rewards. [pdf] Institute of Leadership and Management Research. Available at: $<$ https://www.institutelm.com/> [Accessed 02 October 2017].

Shih, H.C. and Huang, Y.C., 2011. A new mode of learning organization. International Journal of Manpower, 32(5-6), pp.623-644.

Snell, S. and Bohlander, G., 2010. Managing Human Resources. United States: Copyright Act.

Văcărescu Hobeanu, L., 2015. The performances assessment - Assessment methods and techniques of the professional performances. Journal of Applied Economic Sciences, 10(2), pp.262-278. 
Yang, S. and Zhu, Q., 2008. An evaluation model on employee performance based on improved BP neural network. In: IEEE, $4^{\text {th }}$ International Conference on Wireless Communications, Networking and Mobile Computing, 12-17 October 2008. Dalian, China: Institute of Electrical and Electronics Engineers (IEEE).

Wilson, A.M., 2001. The role of mystery shopping in the measurement of service performance. Managing Service Quality: An International Journal, 8(6), pp.414420.

Wong, N.W., 2009. The strategic skills of business continuity managers: putting business continuity management into corporate long-term planning. Journal of Business Continuity \& Emergency Planning, 4(1), pp.62-68.

\section{ABOUT AUTHORS}

Hana Urbancová, Ph.D., Department of Human Resources, University of Economics and Management in Prague, Prague 2600/9a, 158 00, Czech Republic. Main research interests: human resource management, age management, strategic management, knowledge management and knowledge continuity management, e-mail: hana.urbancova@vsem.cz.

Katarina Stachová, associate professor, Department of Management, School of Economics and Management in Public Administration in Bratislava, Furdekova 16, 85104 Bratislava, Slovak Republic. Main research interests: human resource management, management, e-mail: katarina.stachova@vsemvs.sk.

Zdenko Stacho, associate professor, Department of Management, School of Economics and Management in Public Administration in Bratislava, Furdekova 16, 85104 Bratislava, Slovak Republic. Main research interests: Strategic management and human resource management, e-mail: zdenko.stacho@vsemvs.sk. 